\section{Nauplius}

The Journal OF The

Brazilian Crustacean Society

e-ISSN 2358-2936

www.scielo.br/nau www.crustacea.org.br

\title{
Carcinoplax mistio, a new species of goneplacid crab from the Indian Ocean (Decapoda: Brachyura: Goneplacoidea)
}

\author{
Peter K. L. Ng 1 (1) orcid.org/0000-0001-5946-0608
}

Santanu Mitra² ${ }^{2}$ orcid. org/0000-0002-3247-9293

\begin{abstract}
1 Lee Kong Chian Natural History Museum, Faculty of Science, National University of Singapore. 2 Conservatory Drive, Singapore 117377, Republic of Singapore. PKLN E-mail: peterng@nus.edu.sg

2 Crustacea Division, Zoological Survey of India. Fire Proof Spirit Building, 27 J. L. Nehru Road, Kolkata-700016, West Bengal, India.

SM E-mail: santanuzsi@gmail.com

ZOOBANK: http://zoobank.org/urn:1sid:zoobank.org:pub:0302A867-CBEC-4A099870-CB9A39FF25FE
\end{abstract}

\begin{abstract}
Trawls from the Bay of Bengal obtained material of a new species of the goneplacid crab, Carcinoplax mistio, the sixth species of the genus known from India. The new species superficially resembles C. purpurea Rathbun, 1914, and C. sinica Chen, 1984, from the western Pacific. Records of C. sinica from the Persian Gulf are also here referred to the new species. Carcinoplax mistio n. sp. differs from its closest congeners mainly in the form of the carapace, anterolateral armature, proportions of the ambulatory legs and structure of the male pleon.
\end{abstract}

\section{KeYWORDS}

taxonomy, Goneplacidae, Indo-Pacific region, Carcinoplax, Bay of Bengal, India

\section{INTRODUCTION}

Eight species of Carcinoplax H. Milne Edwards, 1852 (family Goneplacidae), are now known from the Indian Ocean (including the Red Sea): C. fasciata Ng and Kumar, 2016; C. indica Doflein, 1904; C. specularis Rathbun, 1914; C. longipes (Wood-Mason, in Wood-Mason and Alcock, 1891); C. ischurodous (Stebbing, 1923); C. longimanus (De Haan, 1833); C. monodi Guinot, 1989; and C. sinica Chen, 1984 (cf. Guinot, 1989; Castro, 2007, 2012, 2013; Ng and Kumar, 2016; Naderloo, 2017). Of these, five are known from India: C. fasciata, C. indica, C. specularis, C. longipes and $C$. longimanus (see Trivedi et al., 2018).

Recently, the authors examined three specimens initially identified as C. sinica collected by fishermen from the Bay of Bengal. This species was 
originally described from the South China Sea by Chen (1984) but has since been reported from the Philippines, Taiwan and Persian Gulf (Guinot, 1989; Hsueh and Huang, 2002; Castro, 2007; Naderloo, 2017; $\mathrm{Ng}$ et al., 2017). Close comparisons with material of $C$. sinica s. str. from the western Pacific (including topotypic material) showed that the Indian specimens belong to a different species, here named Carcinoplax mistio n. sp.

\section{Material and Methods}

Specimens examined are deposited in the Zoological Survey of India (ZSI), Calcutta, India; and Zoological Reference Collection (ZRC) of the Lee Kong Chian Natural History Museum, National University of Singapore. Measurements (in millimetres) of the material examined are of the maximum carapace width (including teeth) and length, respectively. Male pleonal somite 6 is measured along its widest part (on the proximal margin) and the maximum length along the median line, while the male telson is measured along its longest and widest points. The following abbreviations are used: P2-P5 = first to fourth ambulatory legs, respectively; G1 and G2 = male first and second gonopods, respectively. The terminology used follows $\mathrm{Ng}$ et al. (2008) and Davie et al. (2015).

\section{Systematics}

\section{Superfamily Goneplacoidea MacLeay, 1838}

\section{Family Goneplacidae MacLeay, 1838}

Genus Carcinoplax H. Milne Edwards, 1852 s. str.

\section{Carcinoplax mistio n. sp.}

(Figs. 1, 2, 6A, B, 7A, G, H, 8A-G, 9A, B)

Carcinoplax (purpurea) ? - Stephensen, 1946: 166, 208, fig. 44 (not Carcinoplax purpurea Rathbun, 1914).

Carcinoplax purpurea - Guinot, 1967: 276 (list); Titgen, 1982: 252 (list) (not Carcinoplax purpurea Rathbun, 1914).

Carcinoplax sinica - Guinot, 1989: 285, text-fig. 14A, B, pl. 5 figs. A, B, B1, C, C1, D, E, E1; Apel, 2001 : 101; Naderloo and Sari, 2007: 449; Naderloo, 2017: 69, text-fig. 11.2d, e, fig. 12.1 (not Carcinoplax sinica Chen, 1984).
Type material. Holotype: male $(29.2 \times 19.0 \mathrm{~mm})$ (ZSI Reg. No. C7123/2), Fresargunj Fishing Harbour, trawl by-catch, District 24 Pargana (South), West Bengal, Bay of Bengal, India, coll. local fishermen, 24 February 2017. Paratypes: 1 female (36.4 x 24.2 $\mathrm{mm}$ ) (ZSI Reg. No. C7124/2), same data as holotype; 1 female $(36.7 \times 27.5 \mathrm{~mm})$ (ZSI), same location as holotype, coll. local fishermen, 28 July 2018.

Comparative material. Carcinoplax purpurea Rathbun, 1914: 1 male ( $31.7 \times 24.3 \mathrm{~mm}), 2$ females (larger $38.8 \times 29.5 \mathrm{~mm}$ ) (ZRC 2001.0017), Tahsi, Ilan County, northeastern Taiwan, coll. K.-X. Li, 2000; 1 male $(31.0 \times 24.2 \mathrm{~mm})$ (ZRC 1999.0773), Tashi port, Ilan County, northeastern Taiwan, coll. P.K.L. Ng and K. Lim, May 1999. - Carcinoplax sinica Chen, 1984: 1 male $(31.7 \times 20.9 \mathrm{~mm})$ (ZRC 2011.0607), station 6215 , sand-mud substrate, Gulf of Tonkin, South China Sea, $48 \mathrm{~m}$, China-Vietnam Cooperative Expedition of Comprehensive Oceanographic Investigation on Beibu Gulf (Gulf of Tonkin) 1959-1960, trawl, coll. 18 April 1960; 1 juvenile female (30.2 x 19.3 mm) (ZRC 2011.0609), station 6234, muddy-sand substrate, Gulf of Tonkin, South China Sea, 30 m, ChinaVietnam Cooperative Expedition of Comprehensive Oceanographic Investigation on Beibu Gulf (Gulf of Tonkin) 1959-1960, trawl, coll. 21 April 1960; 1 male (28.5 x $19.5 \mathrm{~mm})$ (ZRC 1984.5693), near Horsburg Lighthouse, about $241.4 \mathrm{~km}$ off Singapore, South China Sea, coll. trawlers, H. Huat, 28 August 1983; 2 females $(35.9 \times 25.6 \mathrm{~mm}, 30.6 \times 21.0 \mathrm{~mm})$ (ZRC 1984.63126313 ), about $48.3 \mathrm{~km}$ from Horsburg Lighthouse, South China Sea, off Singapore, coll. trawlers, H. Huat, 10 September 1983 ; 1 male $(35.2 \times 23.4 \mathrm{~mm}), 1$ female (42.8 x $29.2 \mathrm{~mm})$ (ZRC 1984.7842-7843), Horsburg Lighthouse, South China Sea, near Singapore, coll. trawlers, H. Huat, 26 November 1982 and 15 December 1982; 1 male (34.6×25.0 mm) (ZRC 1984.6314), near Horsburg Lighthouse, about $241.4 \mathrm{~km}$ off Singapore, South China Sea, coll. trawlers, H. Huat, 28 August 1983; 1 female (44.0 x $29.3 \mathrm{~mm}$ ) (ZRC 2001.0136), Tungkang, Kaohsiung County, southwestern Taiwan, coll. L.-S. Huang, 4 August 1996.

Etymology. The name is derived from the Latin "mistio" for "a mixture"; alluding to the mix of diagnostic characters in this species which are shared with $C$. purpurea and C. sinica. The name is used as a noun. 


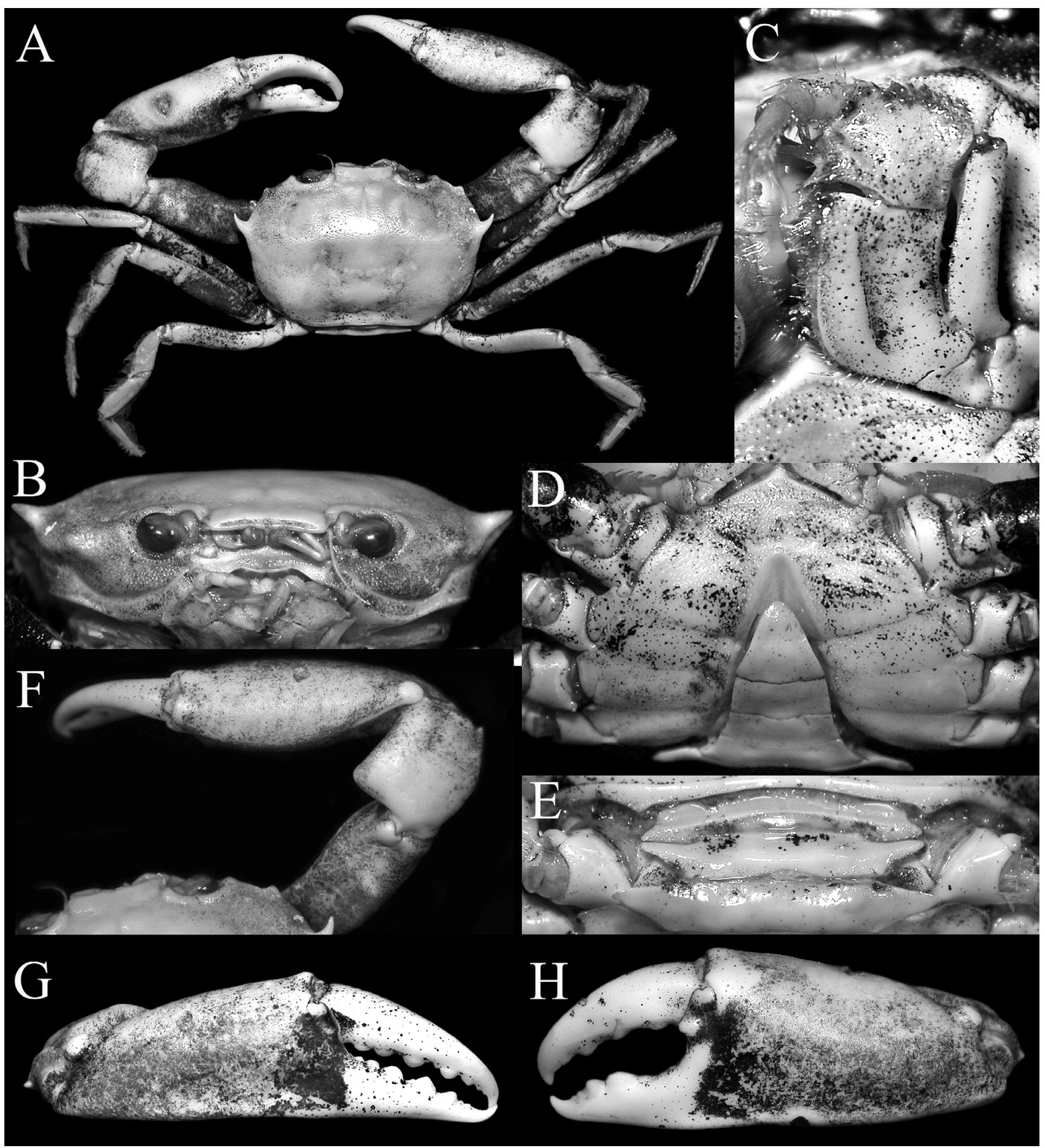

Figure 1. Carcinoplax mistio n. sp., holotype male (29.2 x 19.0 mm) (ZSI Reg. No. C7123/2), Bay of Bengal. A, overall habitus; B, frontal view of cephalothorax; C, left third maxilliped; D, anterior thoracic sternum, pleonal somites 4-6 and telson; E, posterior thoracic sternum and pleonal somites 1-3; F, dorsal view of right cheliped; G, outer view of right chela; $\mathrm{H}$, outer view of left chela.

Diagnosis. Carapace transversely hexagonal, 1.331.54 times wider than long; dorsal surface gently convex, smooth, lateral surfaces with densely packed low, rounded granules; epigastric region low but visible; postorbital regions not clearly demarcated; frontal margin lamellar, truncate, bilobed with small median notch; anterolateral margin with first tooth very low not spiniform, second tooth long, acute, sharp, curving gently obliquely anteriorly; posterolateral margin gradually converging towards gently sinuous posterior carapace margin; posterior margin of epistome with prominent but low triangular median projection; merus of third maxilliped with anteroexternal margin auriculiform; dorsal margin 


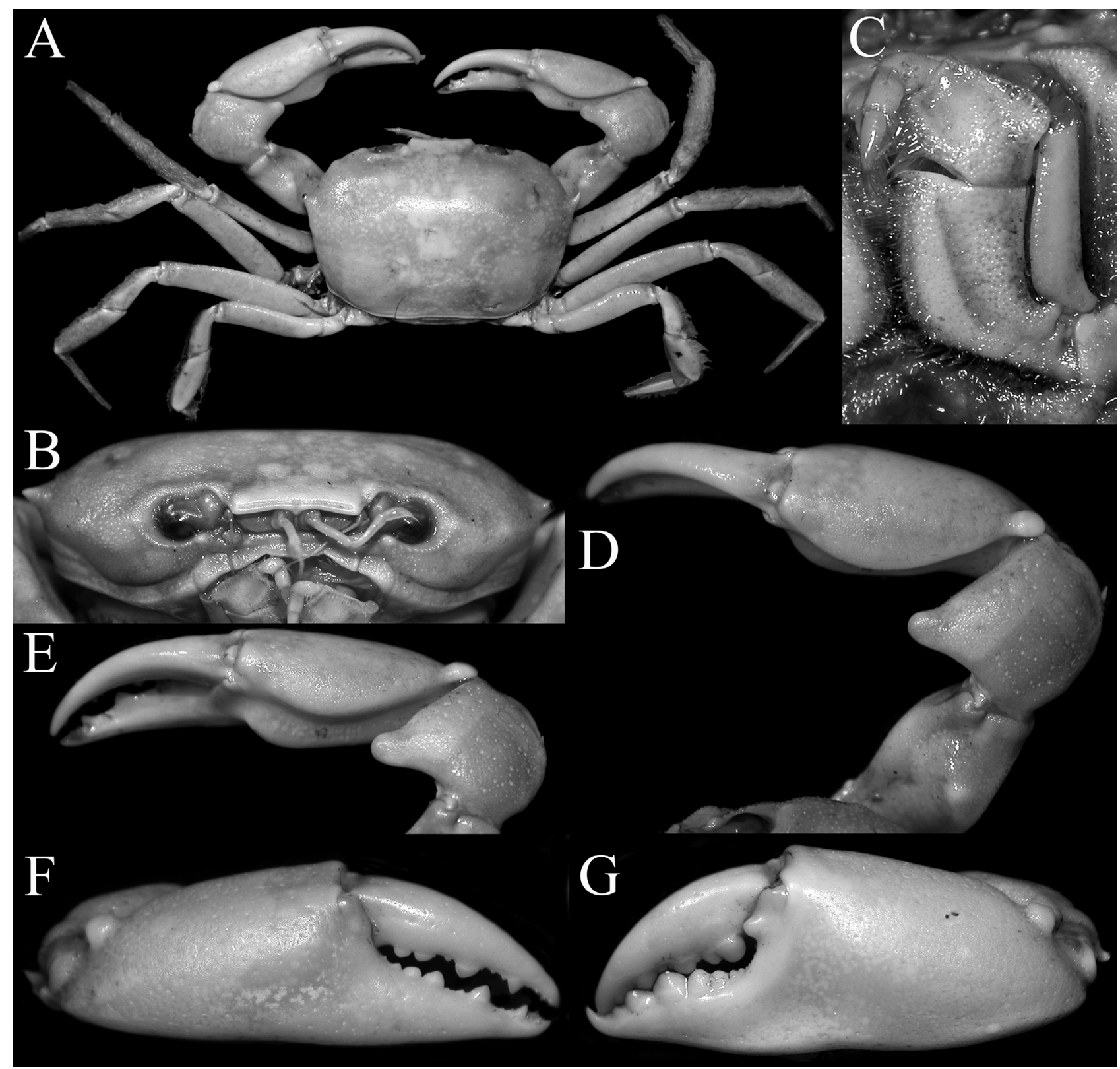

Figure 2. Carcinoplax mistio n. sp., paratype female (36.4 x $24.2 \mathrm{~mm})$ (ZSI Reg. No. C7124/2), Bay of Bengal. A, overall habitus; $\mathrm{B}$, frontal view of cephalothorax; C, left third maxilliped; D, E, dorsal view of right cheliped (viewed at slightly different angles); F, outer view of right chela; $\mathrm{G}$, outer view of left chela.

of cheliped palm rounded, smooth; carpus of male cheliped with low rounded tooth on distal inner angle; merus elongate with low rounded tooth on distal third of dorsal margin; ambulatory legs (P2-P5) slender, long; thoracic sternum surface covered with numerous small, rounded, densely packed granules; sternopleonal cavity extending to about two-thirds of sternite 4, reaching imaginary line connecting proximal part of coxae of chelipeds; male pleon triangular, transversely broad, telson broadly triangular, somite 6 transversely rectangular, much wider than long; G1 relatively slender, distal two-thirds almost straight; distal part slightly flared, laterally flattened, subtruncate; G2 much longer than G1, distal segment flagelliform, about three-quarters length of basal segment; vulvae ovate, large, level with surface of sternum.

Description of male holotype. Carapace (Figs. 1A, 6A) transversely hexagonal, 1.54 times wider than long; dorsal surface gently convex, smooth, without setae, lateral surfaces with densely packed low, rounded granules; regions poorly defined; epigastric region low but visible, separated by shallow Y-shaped groove; postorbital regions not clearly demarcated; gastro- 
cardiac shallow but visible; external orbital angle low, broadly triangular, surface granular, not extending to frontal margin. Frontal margin (Figs. 1A, 6A) lamellar, truncate, straight, slightly deflexed downwards, with deep transverse submarginal groove; bilobed with shallow but distinct median notch; front separated from supraorbital margin by small but distinct notch. Anterolateral margin (Figs. 1A, 6A) convex, first tooth very low not spiniform; second tooth long, acute, sharp, curving gently obliquely anteriorly; anterolateral margin separated from posterolateral margin by shallow concavity, junction with posterolateral margin gently convex; posterolateral margin gradually converging towards gently sinuous posterior carapace margin. Orbit short, ovate, much shorter than front margin (Figs. 1B, 6A); ocular peduncle stout, very short; cornea large, round. Supraorbital margin (Figs. 1A, 6A) gently concave, lined with very low, small rounded granules, with shallow median groove mostly obscured by granules, lateral end of margin confluent with external orbital tooth. Suborbital margin (Fig. 1B) gently concave, entire, distinctly granulated, with low, rounded inner tooth near base of eye. Suborbital, subhepatic, anterior half of pterygostomial regions (Fig. 1B) covered with small, low rounded densely packed granules. Basal antennular article (Fig. 1B) subrectangular; article 3 rectangular, distal margin touching frontal margin; article 4 shorter than article 3; flagellum long, folding transversely. Basal antennular article (Fig. 1B) subrectangular; article 3 rectangular, distal margin touching frontal margin; article 4 just shorter than article 3; flagellum long, folding transversely. Epistome (Fig. 1B) longitudinally narrow; posterior margin of epistome with prominent but low triangular median projection, with distinct median fissure, separated from gently concave lateral margin by fissure. Endostomial ridge sharp, distinct on anterior part, posterior part low. Third maxillipeds (Fig. 1C) almost completely closing buccal cavern when closed; merus quadrate, anteroexternal margin auriculiform, median part gently depressed; ischium rectangular, with deep submedian oblique sulcus, inner (mesial) margin lined with dense stiff setae; exopod relatively stout with prominent subdistal triangular tooth on inner (mesial) margin, with long flagellum.

Chelipeds (Fig. 1A, F-H) unequal, left chela larger; fingers relatively slender, distinctly shorter than palm; surfaces covered with low, rounded granules, appears rugose in parts; inner surface smooth, with slightly swollen longitudinal median part; pollex of major chela smooth on outer surface, cutting edge with low, rounded teeth; dactylus smooth on outer surface, cutting edge with low, rounded teeth; fingers of minor chela similar to those on major chela except teeth more distinct; carpus subtriangular with low rounded tooth on distal inner angle, outer (lateral) angle with sharp tubercle; merus elongate, trigonal in cross-section, surface with small, rounded granules, dorsal margin with low rounded tooth on distal third.

Ambulatorylegs (P2-P5) (Figs. 1A, 7G, H) slender, long; P3 longest; P2-P5 merus subcylindrical, laterally flattened, outer surface almost smooth or with very low flattened granules, generally glabrous or with scattered setae, ventral margin smooth, dorsal margin with low granules but not serrate; P2-P5 carpus elongate, outer surface and dorsal margin with low granules and setae; P2-P4 propodus long, distinctly laterally flattened, with longitudinal median sulcus (very shallow on P5), lateral margins of distal third with relatively dense setae which partially obscure margin; P2-P4 dactylus elongate, falciform, entire surface except for sharp tip covered with pubescence; P5 shortest, when folded reaching second anterolateral tooth, merus gently curved dorsal margin with very low granules, appearing almost smooth, propodus longitudinally ovate with shallow median sulcus, lateral margins with numerous long setae, dactylus shorter than those on P2-P4, with setae relatively longer; dactylo-propodal lock not developed.

Thoracic sternum (Fig. 1D) relatively wide, surface covered with numerous small, rounded, densely packed granules; sternites 1, 2 completely fused, triangular, lateral margins gently convex, separated from sternite 3 by shallow, gently convex suture, partially obscured by low granules; sternites 3, 4 fused with only lateral part of suture clearly visible, median parts indicated by shallow depressions, partially obscured by low granules; sutures $4 / 5,5 / 6,7 / 8$ medially interrupted, suture $6 / 7$ complete; distinct median longitudinal groove extending across most of sternites 7, 8. Posterior edge of episternite 7 partially overlapping small anterior part of P5 coxa. Sternopleonal cavity (Fig. 1D) deep, extending to about two-thirds of sternite 4, reaching imaginary line connecting median part of coxae of chelipeds; with longitudinal groove on sternite 4; part of sternite 8 (Fig. 1E) exposed between somites 2 and 4 when completely completely closed. Press-button male pleonal locking mechanism present as short peg-like tubercle on anterior margin of sternite 5 , just adjacent 
to sternite 4. Opening for penis coxal, at anterior edge of condyle of P5 coxa; penis short, tubular with distal half wider than proximal part.

Pleon (Figs. 1D, E, 7A) triangular, transversely broad, all somites, telson free; telson broadly triangular, lateral margins almost straight to gently sinuous; somite 6 transversely rectangular, much wider than long, lateral margins gently convex, gently converging towards telson; somites 3-5 wide, trapezoidal, somite 3 widest, lateral parts tapering, edges overlapping part of P5 coxae; somites 1, 2 longitudinally narrow, reaching to P5 coxae.

G1 (Fig. 8A-C) relatively slender, distal two-thirds with mesial margin gently concave; tip slightly flared, laterally flattened, subtruncate; distal surfaces with numerous short spines. G2 (Fig. 8D) slender, much longer than G1, distal segment long, flagelliform, about three-quarters length of basal segment, tip weakly bifurcated.

Female. The carapace of the female paratypes are generally smoother on all their surfaces, with the second anterolateral tooth relatively shorter (Figs. 2A, 6B). The carapaces are also relatively higher with the dorsal surface relatively but distinctly more inflated (Fig. 2B). The inner carpal tooth on the chelipeds are also proportionately longer and the inner surface of the chela more inflated (Fig. 2A, D, E) compared to the male. The chelae of the females are similar in form to the holotype male except that the fingers and palm are relatively shorter (Fig. 2F, G). The pleons are ovate with all the somites and telson free (Fig. 9A). The vulvae are ovate, large, level with the surface of the sternite, covered with stiff membrane, without opercular cover, and positioned on the anterior two-thirds of somite 6 but not reaching the suture with sternite 5 (Fig. 9B).

Colour in life. Carapace whitish; chelipeds and ambulatory legs with the upper parts pale red; ventral surfaces white.

Remarks. The specimens from the Persian Gulf reported as C. sinica by Guinot (1989) and Naderloo (2017) are here also identified with the new species from the Bay of Bengal in India. They agree very well in the diagnostic features of the carapace and ambulatory legs with C. mistio n. sp.

Carcinoplax mistio $\mathrm{n}$. sp. is superficially most similar to C. sinica, in the transversely hexagonal carapace and prominent second anterolateral tooth, which is spiniform and gently curved. It can, however, be reliably distinguished by the structure of the G1. In C. mistion. sp., the mesial margin of the distal two-thirds is gently concave and the tip is elongate (Fig. 8E, F) (versus distal two-thirds of the G1 is straight and the tip is rounded and short in C. sinica; Fig. 8L, N). When specimens of similar sizes are compared, the male pleon of C. mistio n. sp. (holotype $(29.2 \times 19.0 \mathrm{~mm}$, ZSI Reg. No. C7123/2) is proportionately broader (somite 6 and telson 1.93 and 1.11 times wider than long, respectively) (Fig. 7A) (versus pleon of male 28.5 x $19.5 \mathrm{~mm}$ (ZRC 1984.5693), relatively narrower in C. sinica, with the width to length ratio for somite 6 and telson 1.85 and 0.91 times, respectively; Fig. 7D). Larger specimens of $C$. sinica, however, have relatively wider male pleons, although in these specimens, the lateral margins of somite 6 are convex and those of the telson distinctly concave (Fig. 7E, F) (versus lateral margins of somite 6 almost straight and those of the telson slightly concave in C. mistio n. sp.; Fig. 7A). The rounded tooth on the inner angle of the male carpus of the male cheliped is also proportionately shorter in C. mistio n. sp. (Fig. 1F) compared to that of C. sinica, which is distinctly longer (Fig. 4E).

The specimens from the Persian Gulf referred to $C$. sinica by Guinot (1989: 285), Castro (2007: 640) and Naderloo (2017:69) should be referred to C. mistio $\mathrm{n}$. sp. as well. Male specimens from the Persian Gulf have a relatively short rounded tooth on the distal inner angle of the carpus of cheliped ( $c f$. Guinot, 1989: pl. 5 figs. A) as in the type of C. mistio n. sp. (Fig. 1A, F), and their G1 structures are similar in form (Fig. 8A-C, E, F).

It is unfortunate that the distal parts of both G1s of the holotype male of $C$. mistio n. sp. are damaged. In the more intact left G1, only the tip is broken off (Fig. 8B, C), but it is clear from the base that the intact structure would be more elongate and tapering, like that figured for the male from Iran (cf. Fig. 8E, F) rather than the more rounded tip observed for C. sinica (Fig. 8L, N).

Carcinoplax sinica was described from a large series of specimens from the Gulf of Tonkin (= Beibu Wan) in the South China Sea, and the authors have examined two of the non-type specimens (ZRC 2011.0607 and ZRC 2011.609), which had been listed by Chen (1984: 190). It has since been reliably reported from Taiwan, mainland China, Philippines and Vietnam (Serène and Lohavanijaya, 1973; Serène and Vadon, 1981; 
Dai et al., 1986; Guinot, 1989; Dai and Yang, 1991; Hsueh and Huang, 2002; Castro, 2007; Ng et al., 2017) (sometimes incorrectly as C. purpurea).

Although their carapaces are quite different, $C$. mistio n. sp. shares similarly structured male pleons and G1s with C. purpurea. Compared to C. purpurea, however, C. mistio n. sp. has the carapace more transversely hexagonal, with the second anterolateral tooth elongate, gently curved anteriorly and sharp (Fig. 6A, B) (versus carapace more quadrate with the posterolateral margins convex and subparallel, the second anterolateral tooth is low and rounded, and if spine present, it is short, straight and directed anteriorly in C. purpurea; Fig. 6C, D); the dorsal surface of the male carapace is relatively low (Figs. 1A, B, 6A) (versus carapace appears inflated with the dorsal carapace surface prominently convex in C. purpurea; Figs. 3C, 6C, D); and the $\mathrm{P} 2-\mathrm{P} 4$ merus is proportionately more elongate

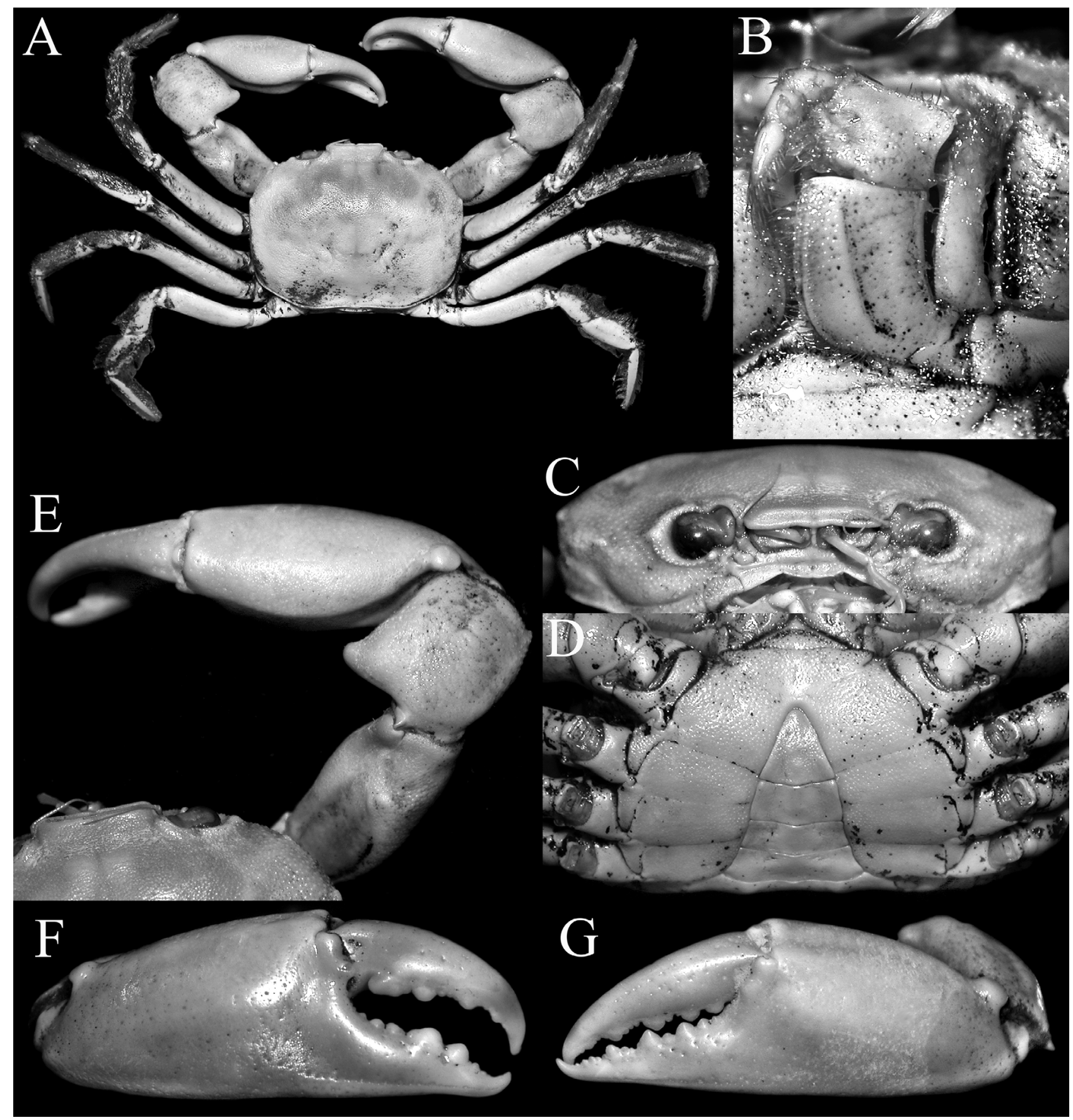

Figure 3. Carcinoplax purpurea Rathbun, 1914, male (31.0 × $24.2 \mathrm{~mm})$ (ZRC 1999.0773), Taiwan. A, overall habitus; B, left third maxilliped; C, frontal view of cephalothorax; D, anterior thoracic sternum, pleonal somites 4-6 and telson; E, dorsal view of right cheliped; F, outer view of right chela; $G$, outer view of left chela. 


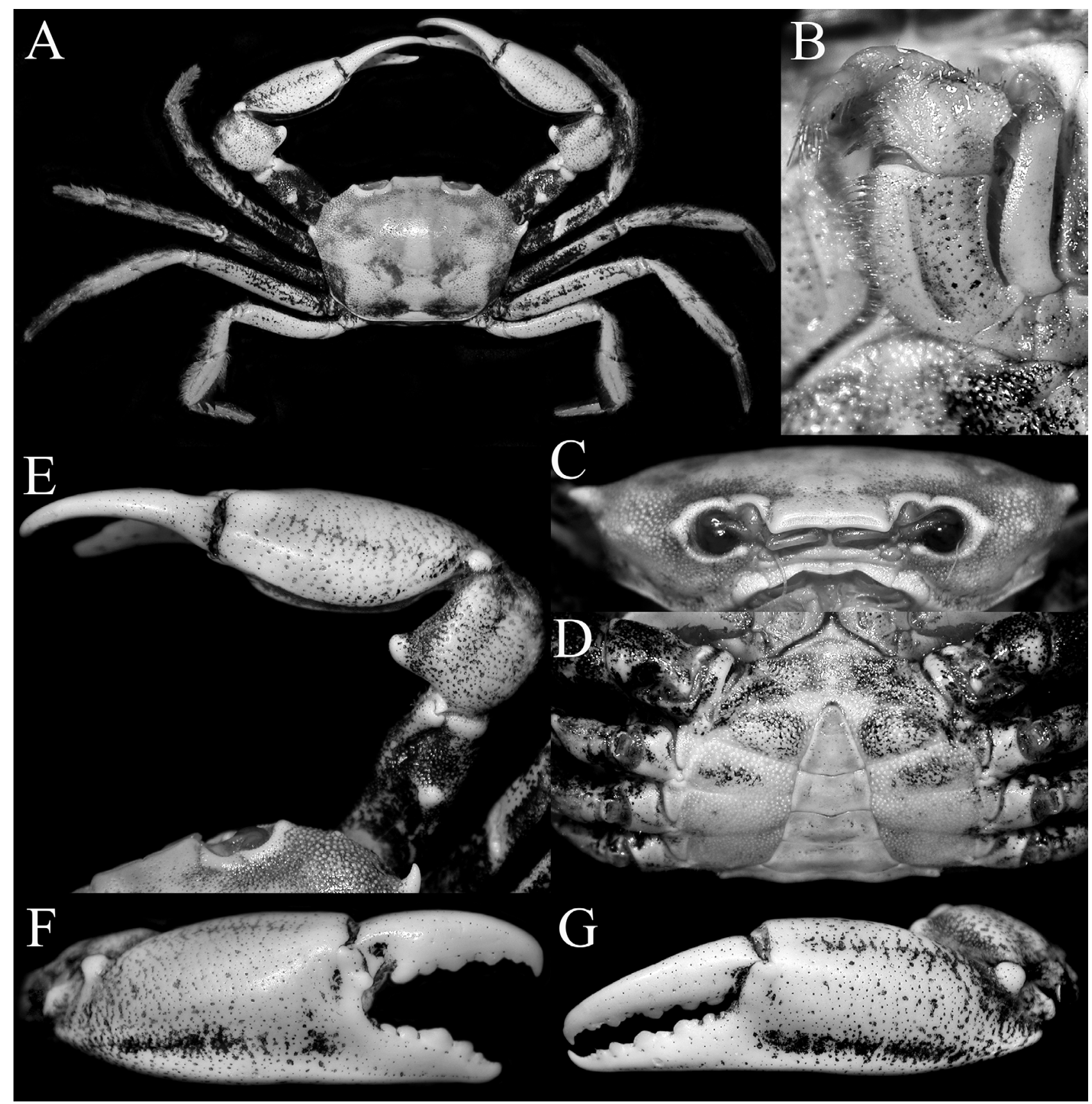

Figure 4. Carcinoplax sinica Chen, 1984, male (28.5 x $19.5 \mathrm{~mm})$ (ZRC 1984.5693), South China Sea. A, overall habitus; B, left third maxilliped; C, frontal view of cephalothorax; D, anterior thoracic sternum, pleonal somites 4-6 and telson; E, dorsal view of right cheliped; F, outer view of right chela; G, outer view of left chela.

and slender (Fig. 7G) (versus the P2-P4 merus shorter and stouter in C. purpurea; Fig. 7I). Carcinoplax purpurea is known for certain only from the west Pacific, with records from Japan, Taiwan, mainland China, Philippines and South China Sea (Rathbun, 1914; Sakai, 1976; Dai et al., 1986; Guinot, 1989; Dai and Yang, 1991; Hsueh and Huang, 2002; Castro, 2007; Ng et al., 2017).
The series of specimens of C. purpurea and $C$. sinica indicate that the carpal spine of adult female specimens is more elongate (Fig. 9C, E) compared to comparably sized males (Figs. 3A, E, 4A, E, 5); and the inner surface of the chela is also relatively more inflated. The same pattern is observed for C. mistio $\mathrm{n}$. sp. (Figs. 1A, F, 2A, D, E). 


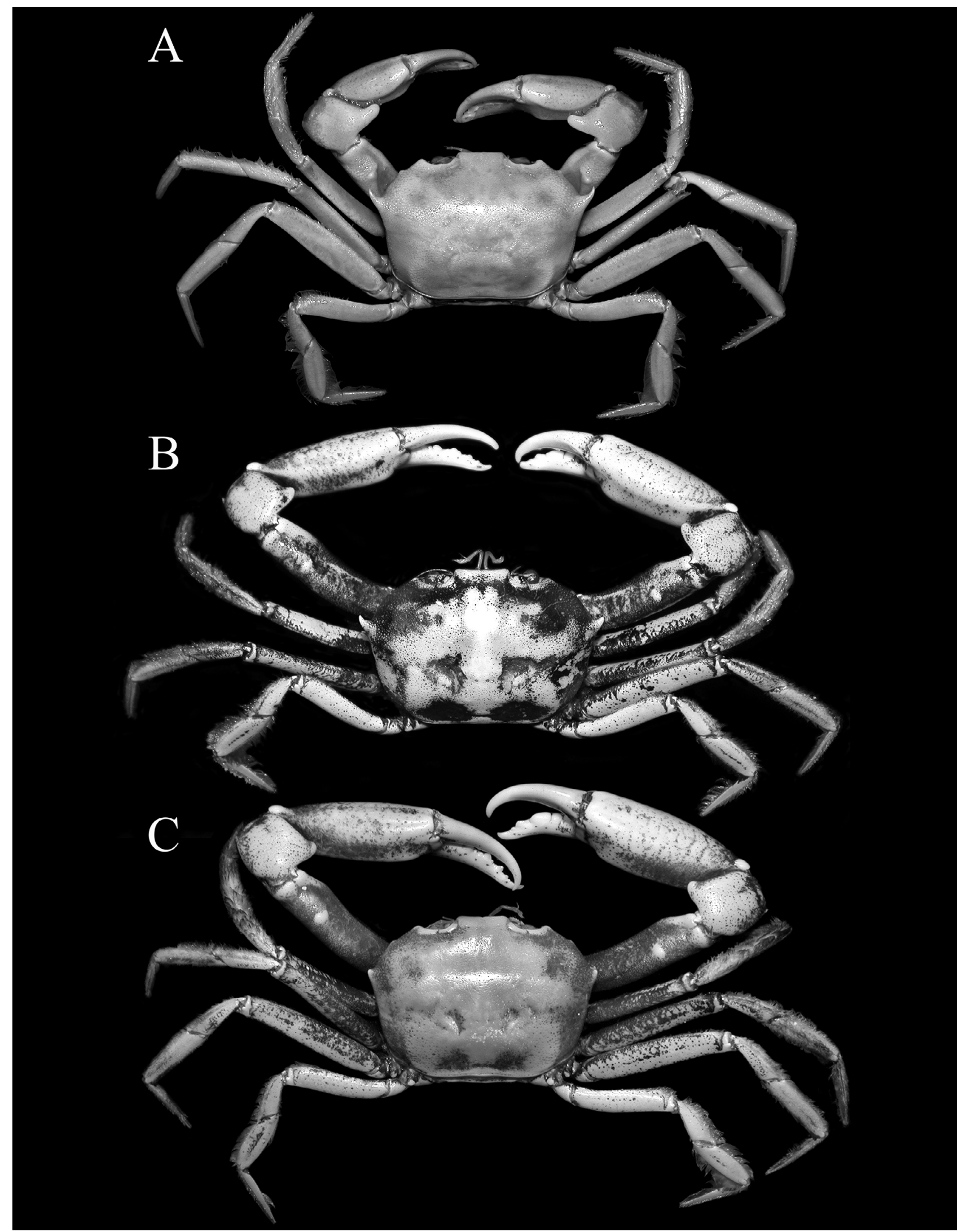

Figure 5. Carcinoplax sinica Chen, 1984, overall habitus. A, male (31.7 x $20.9 \mathrm{~mm})$ (ZRC 2011.0607), Gulf of Tonkin; B, male (35.2 x $23.4 \mathrm{~mm}$ ) (ZRC 1984.7842), South China Sea; C, male (34.6 x $25.0 \mathrm{~mm}$ ) (ZRC 1984.6314), South China Sea. 


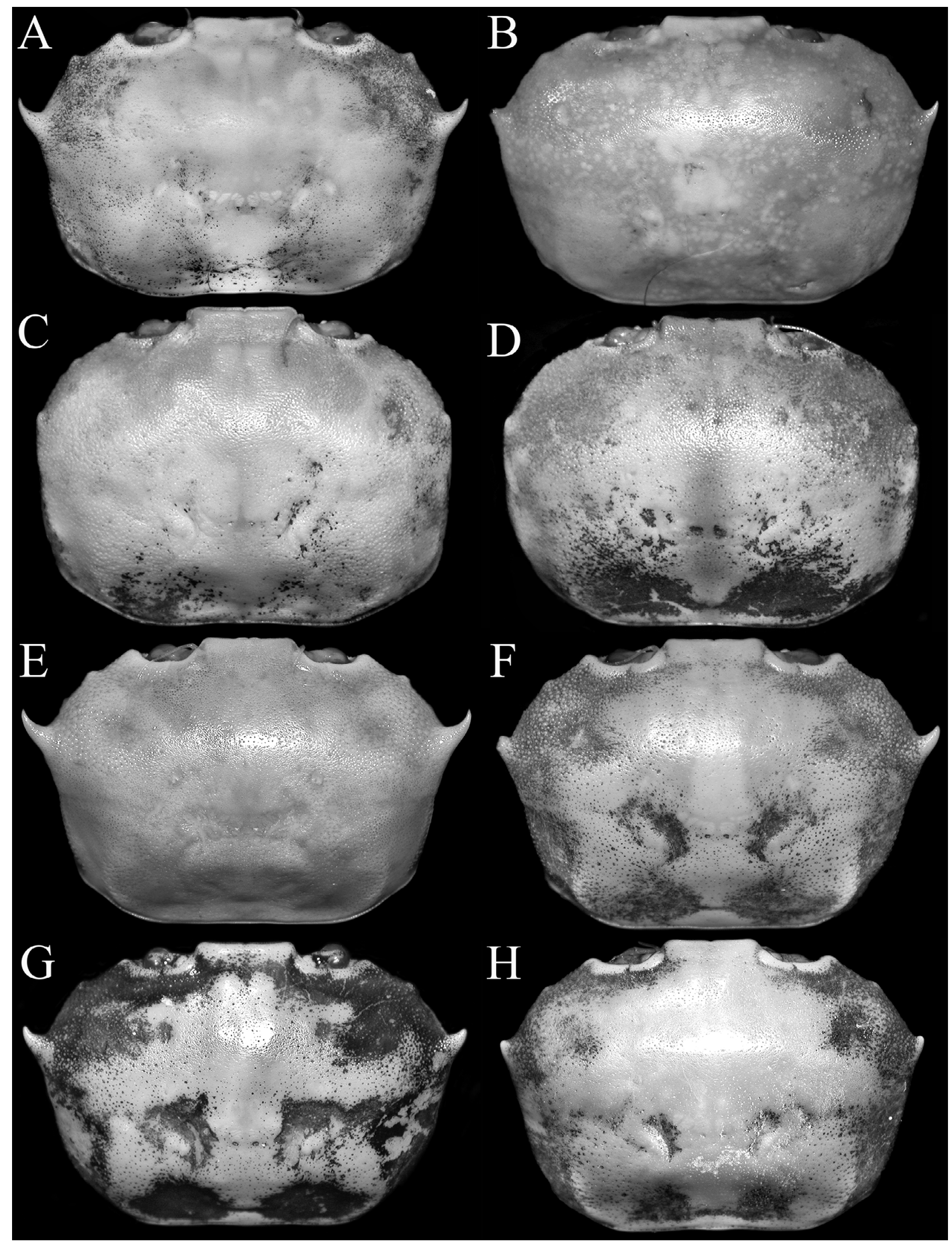

Figure 6. Dorsal view of male carapace. A, Carcinoplax mistio n. sp., holotype male (29.2 x 19.0 mm) (ZSI Reg. No. C7123/2), Bay of Bengal; B, C. mistio n. sp., paratype female (36.4 x $24.2 \mathrm{~mm}$ ) (ZSI Reg. No. C7124/2), Bay of Bengal; C, C. purpurea Rathbun, 1914 (31.0 x $24.2 \mathrm{~mm}$ ) (ZRC 1999.0773), Taiwan; D, C. purpurea (31.7 x $24.3 \mathrm{~mm}$ ) (ZRC 2001.0017), Taiwan; E, C. sinica Chen, 1984 (31.7 x $20.9 \mathrm{~mm}$ ) (ZRC 2011.0607), Gulf of Tonkin; F, C. sinica (28.5 x 19.5 mm) (ZRC 1984.5693), South China Sea; G, C. sinica $(35.2 \times 23.4 \mathrm{~mm})$ (ZRC 1984.7842), South China Sea; H, C. sinica (34.6 x $25.0 \mathrm{~mm})$ (ZRC 1984.6314), South China Sea. 


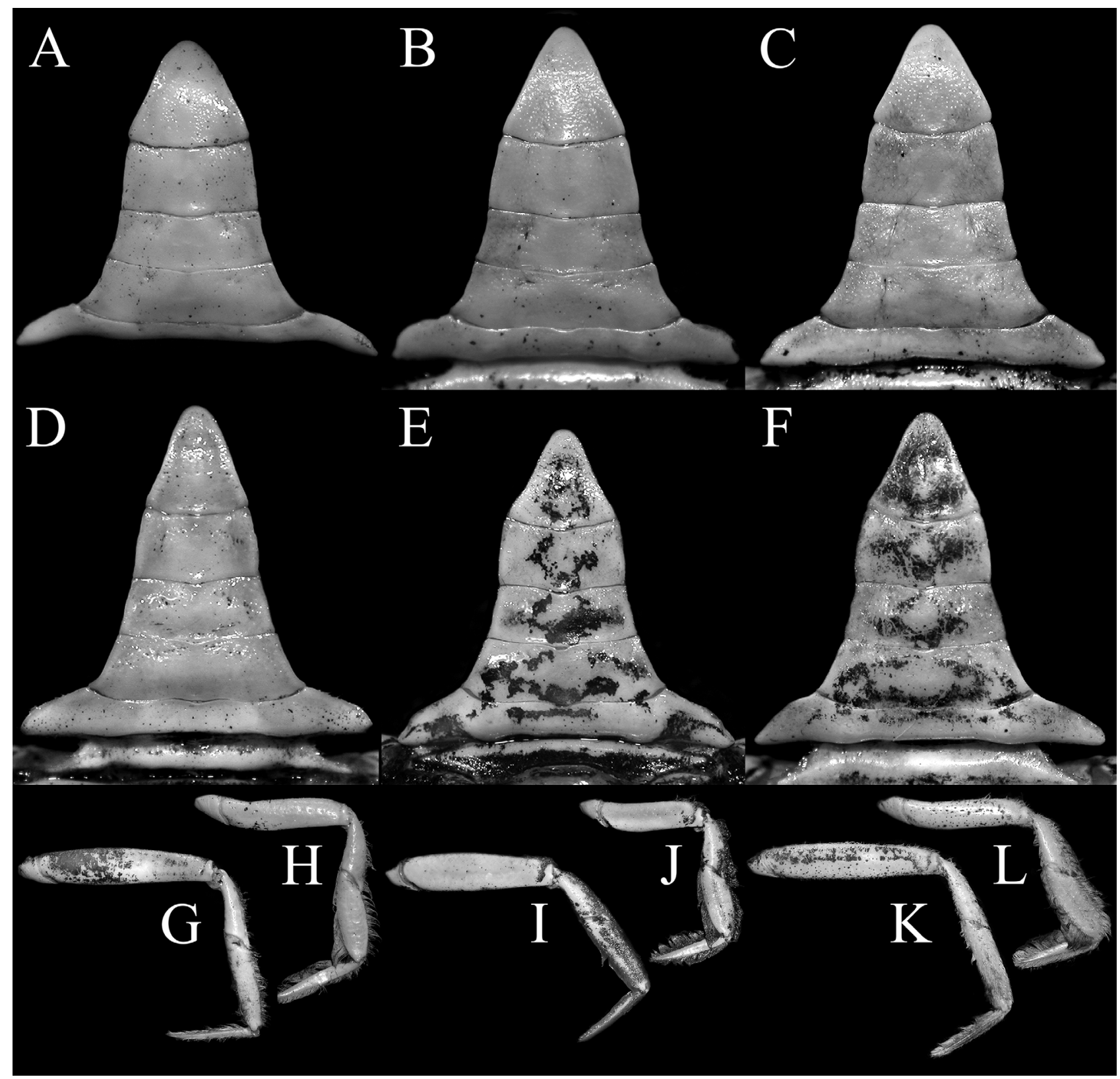

Figure 7. Male pleon and ambulatory legs. A, G, H, Carcinoplax mistio n. sp., holotype male (29.2 x 19.0 mm) (ZSI Reg. No. C7123/2), Bay of Bengal; B, I, J, C. purpurea Rathbun, 1914, male (31.0 x 24.2 mm) (ZRC 1999.0773), Taiwan; C, C. purpurea Rathbun, 1914, male (31.7 x 24.3 mm) (ZRC 2001.0017), Taiwan; D, K, L, C. sinica (28.5 x 19.5 mm) (ZRC 1984.5693), South China Sea; E, C. sinica (35.2 x $23.4 \mathrm{~mm})$ (ZRC 1984.7842), South China Sea; F, C. sinica (34.6 x $25.0 \mathrm{~mm})$ (ZRC 1984.6314), South China Sea. A-F, male pleonal somites 3-6 and telson; G, I, K, right P4; H, J, L, right P5.

The discovery of the present new Carcinoplax species is not surprising; the first goneplacid being C. fasciata, which had been confused with C. specularis (see Ng and Kumar, 2016). Recent studies have shown that an increasing number of brachyuran species which have previously believed to occur in both Indian and west Pacific waters are actually separate taxa, even if they are relatively shallow water taxa (e.g., see Castro and $\mathrm{Ng}, 2010 ; \mathrm{Ng}$ and Castro, 2013, 2016; Ng and Kumar, 2016; Ng and Richer de Forges, 2015; Ng et al., 2018). As reviewed in Trivedi et al. (2018), many Indian taxa will need to be compared with their Pacific and/or Southeast Asian counterparts, ostensibly the same species, to ascertain their actual identities. 


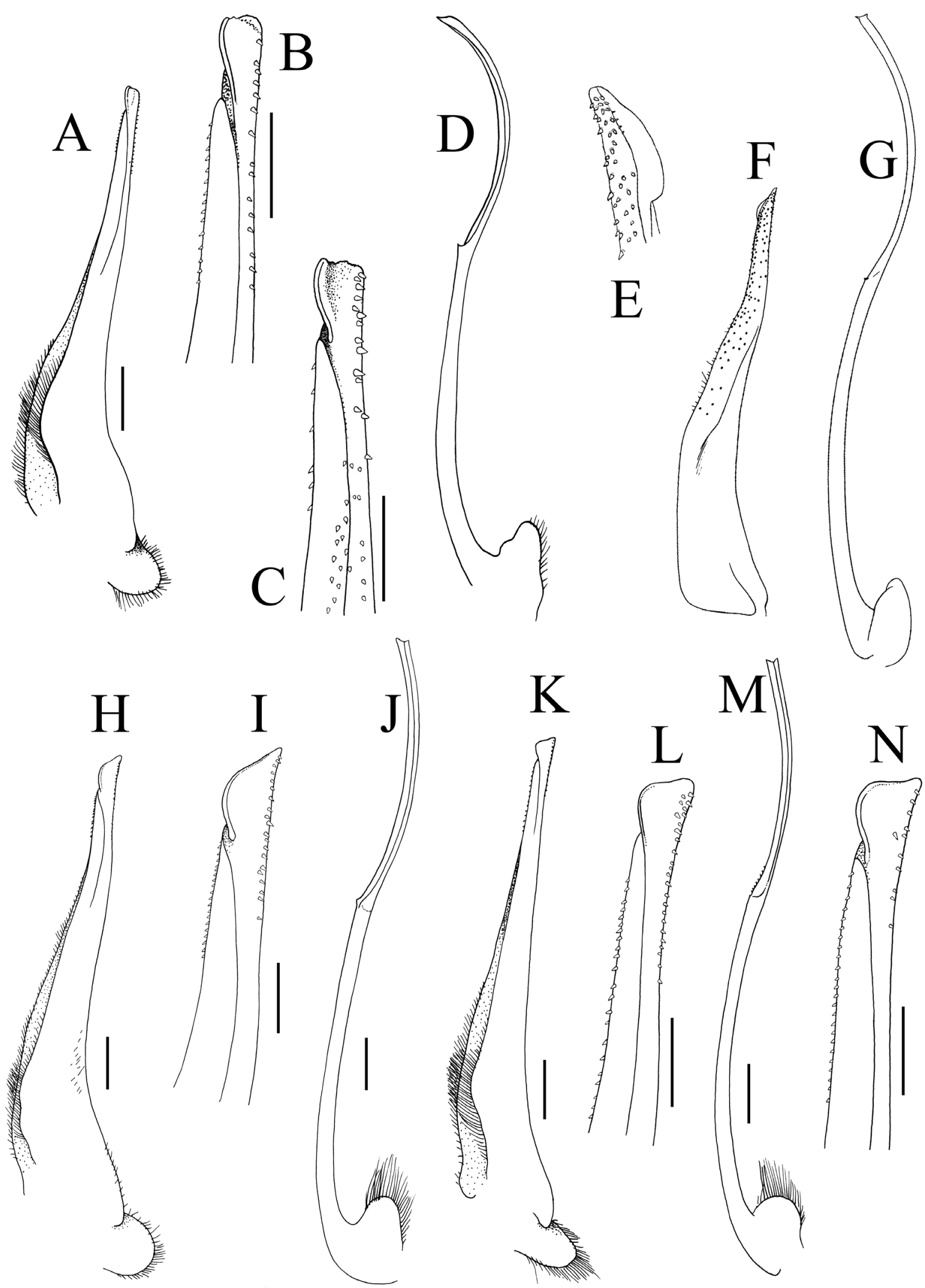

Figure 8. Gonopods. A-D, Carcinoplax mistio n. sp., holotype male (29.2 x 19.0 mm) (ZSI Reg. No. C7123/2), Bay of Bengal; E-J, C. mistio n. sp., K-M, male (45.0 x 29.0 mm) (Copenhagen Museum), Persian Gulf; H-J, C. purpurea Rathbun, 1914, male (31.0 x $24.2 \mathrm{~mm}$ ) (ZRC 1999.0773), Taiwan; K-M, C. sinica Chen, 1984, male (31.7 x $20.9 \mathrm{~mm}$ ) (ZRC 2011.0607), Gulf of Tonkin; N, C. sinica Chen, 1984, male (34.6 x 25.0 mm) (ZRC 1984.6314), South China Sea. A, H, K, left G1 (ventral view); B, C, I, L, N, distal part of left G (ventral view); D, right G2 (transposed for comparative purposes); E, distal part of G1; F, G1; G, G2; J, M, left G2. (E, after Stephensen, 1946: fig. 44A, B; F, G, after Guinot, 1989: fig. 14). Scales: A, D, H, J, K, M = 1.0 mm; B, C, I, L, N = 0.5 mm. 


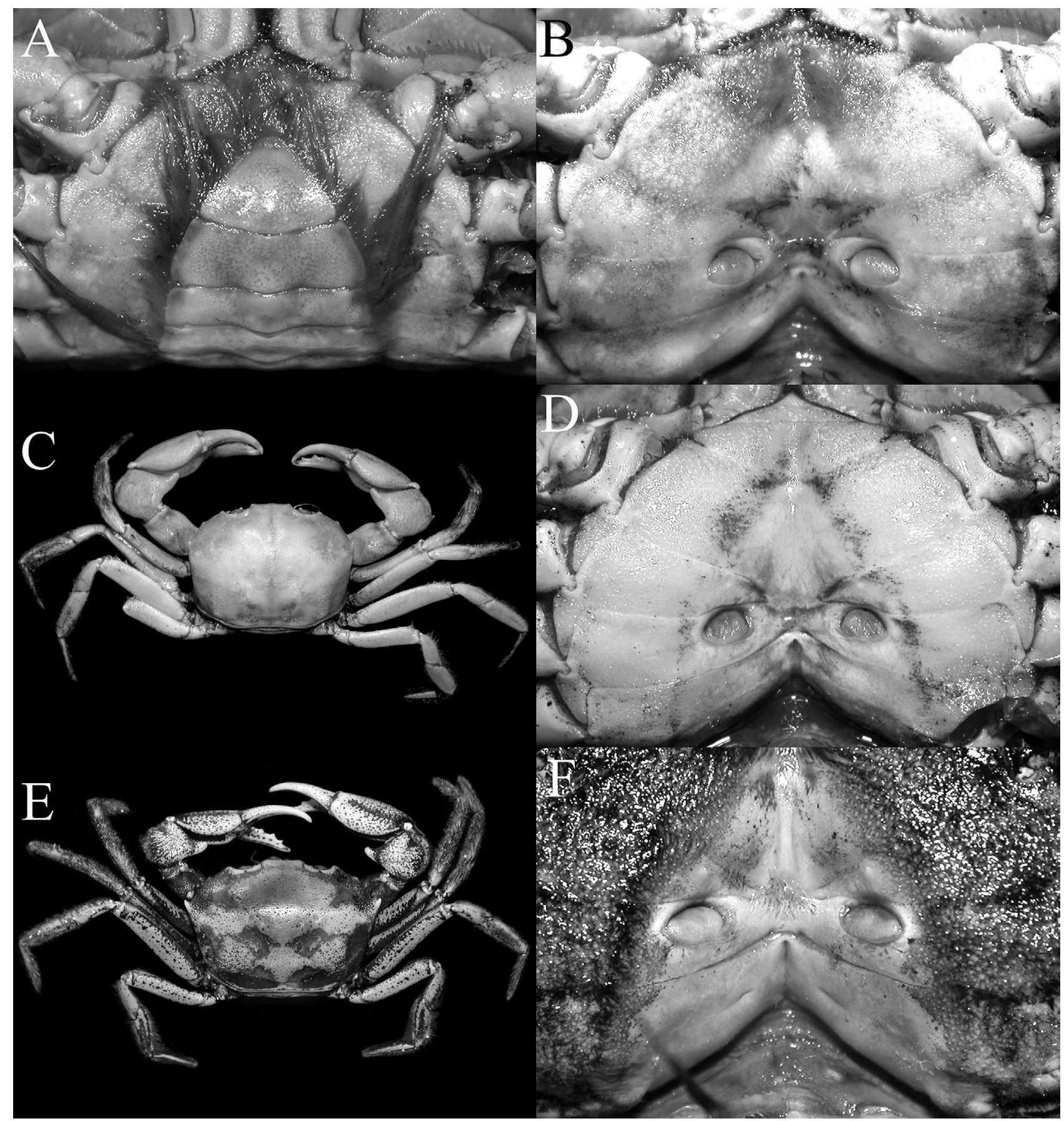

Figure 9.A, B, Carcinoplax mistio n. sp., paratype female (36.4× $24.2 \mathrm{~mm})$ (ZSI Reg. No. C7124/2), Bay of Bengal; C, D, Carcinoplax purpurea Rathbun, 1914, female (38.8 x $29.5 \mathrm{~mm}$ ) (ZRC 2001.0017), Taiwan; E, F, C. sinica Chen, 1984, female (35.9 x 25.6 mm) (ZRC 1984.6313) South China Sea. A, anterior thoracic sternum and pleon; C, E, overall habitus; B, D, F, sternopleonal cavity showing vulvae.

\section{ACKNOWLEDGEMENTS}

The second author (SM) is most thankful to the Director, Zoological Survey of India, Kolkata, for encouragement during this study and providing research facilities. The first author thanks Li Xin Zheng from the Chinese Academy of Sciences (Qingdao) for

help with some of the Chinese data. The second author's visit was facilitated by a Visiting Research Fellowship from the Lee Kong Chian Natural History Museum. Thanks are due to Peter Castro and an anonymous reviewer for their many kind comments, which have significantly improved the paper. 


\section{References}

Apel, M. 2001. Taxonomie und Zoogeographie der Brachyura, Paguridea und Porcellanidae (Crustacea: Decapoda) des Persisch-Arabischen Golfes. Johann Wolfgang GoetheUniversität, Biologie und Informatik, Frankfurt am Main, Germany, Doctoral dissertation, 260p. [Unpublished]

Castro, P. 2007. A reappraisal of the family Goneplacidae MacLeay, 1838 (Crustacea, Decapoda, Brachyura) and revision of the subfamily Goneplacinae, with the description of 10 new genera and 18 new species. Zoosystema, 29: 609-774.

Castro, P. 2009. Two new species of Carcinoplax H. Milne Edwards, 1852, and Pycnoplax Castro, 2007, from the western Pacific, and a description of the female of Thyraplax truncata Castro, 2007 (Crustacea, Decapoda, Brachyura, Goneplacidae). Zoosystema, 31: 949-957.

Castro, P. 2012. Goneplacid crabs (Decapoda, Brachyura, Goneplacidae) of the Mainbaza and Miriki Expeditions to the Mozambique Channel, with the description of a new species of Pycnoplax Castro, 2007.p. 91-104. In: H. Komatsu, J. Okuno and K. Fukuoka (eds), Studies on Eumalacostraca: a homage to Takeda Masatsune. Crustaceana Monographs.

Castro, P. 2013. Brachyuran crabs (Crustacea, Brachyura: Crossotonotidae, Ethusidae, Euryplacidae, Goneplacidae, Latreilliidae, Palicidae, Tetraliidae, Trapeziidae) of the MAINBAZA, MIRIKI, and ATIMO VATAE expeditions to the Mozambique Channel and Madagascar. In: S.T. Ahyong, T.-Y. Chan, L. Corbari and P.K.L. Ng (eds), Tropical DeepSea Benthos. Vol. 27. Mémoires du Muséum national d'Histoire naturelle, 204: 437-466.

Castro, P. and Ng, P.K.L. 2010. Revision of the family Euryplacidae Stimpson, 1871 (Crustacea: Decapoda: Brachyura: Goneplacoidea). Zootaxa, 2375: 1-130.

Chen, H. 1984. A study of the genus Carcinoplax (Crustacea, Decapoda: Goneplacidae) of Chinese waters. Oceanologia et Limnologia Sinica, 15: 188-201, pl. 1.

Dai, A.Y. and Yang, S.L. 1991. Crabs of the China Seas. Beijing, China Ocean Press, and Berlin, Springer-Verlag, 21+608 p., 295 figs., 74 pls.

Dai, A.Y.; Yang, S.L.; Song, Y.Z. and Chen, G.X. 1986. Crabs of the China Seas. Beijing, China Ocean Press, 11+642p. (in Chinese)

Davie, P.J.F.; Guinot, D. and Ng, P.K.L. 2015. Anatomy and functional morphology of Brachyura. p. 11-163. In: P. Castro, P.J.F. Davie, D. Guinot, F.R. Schram and J.C. Von Vaupel Klein (eds), Treatise on Zoology - Anatomy, Taxonomy, Biology. The Crustacea, 9C-I: Decapoda: Brachyura (part 1). Leiden, Brill.

Doflein, F. 1904. Brachyura. In: Wissenschaftliche Ergebnisse der Deutschen Tiefsee-Expedition auf dem Dampfer "Valdivia" 1898-1899, Verlag von Gustav Fischer, Jena, 6: 1-6+i-xiv + 1-314p., figs. 1-58, Atlas: pls. 1-58.

Guinot, D. 1967. La faune carcinologique (Crustacea, Brachyura) de l'Ocean Indien occidental et de la Mer Rouge. Catalogue remarques biogéographiques et bibliographie. Mémoires de l'Institut fundamental d'Afrique noire, 77: 235-352.

Guinot, D. 1989. Le genre Carcinoplax H. Milne Edwards, 1852 (Crustacea, Brachyura: Goneplacidae). In: J. Forest. (ed), Résultats des Campagnes MUSORSTOM, 5. Mémoires du Muséum national d'Histoire naturelle, Paris, (A) 144: 265-345.
Haan, H.M. De 1833-1849. Crustacea. In: P.F. von Siebold (ed), Fauna Japonica, sive Descriptio animalium, quae in itinere per Japoniam, jussu et auspiciis superiorum, qui summum in India Batavia imperium tenent, suscepto, annis 1823-1830 collegit, notis, observationibus a adumbrationibus illustravit. Lugduni Batavorum, fasc. 1-8: I-xxi+vii-xvii+ix-xvi+1-243, pls. 1-55, A-Q, circ., pl. 2.

Hsueh P.W. and Huang J.F. 2002. Crabs of the family Goneplacidae (Decapoda, Brachyura) from Taiwan. Crustaceana, 75: 111-136.

MacLeay, W.S. 1838. On the Brachyurous Decapod Crustacea. Brought from the Cape by Dr. Smith. In: Smith, A., Illustrations of the Zoology of South Africa; consisting chiefly of figures and descriptions of the objects of natural history collected during an expedition into the interior of South Africa, in the years 1834, 1835, and 1836; fitted out by 'The Cape of Good Hope Association for Exploring Central Africa': together with a summary of African Zoology, and an inquiry into the geographical ranges of species in that quarter of the globe, published under the Authority of the Lords Commissioners of Her Majesty's Treasury, Invertebratae. IV [1849]. p. 53-71, pls. 2, 3. Smith, Elder \& Co., London.

Milne Edwards, H. 1852. Observations sur les affinités zoologiques et la classification naturelle des Crustacés. Annales des Sciences naturelles, Zoologie, (3) 18: 109-166, pl. 3, 4. (Second part in Annales des Sciences naturelles, Zoologie [Paris] 20: 163-228, pls. 6-11 [1853]).

Naderloo, R. 2017. Atlas of Crabs of the Persian Gulf. Cham, Springer, 440p.

Naderloo, R. and Sari, A. 2007. Subtidal crabs of the Iranian coast of the Persian Gulf: new collections and biogeographic considerations. Aquatic Ecosystem Health Management, 10: 341-349.

Ng, P.K.L. and Castro, P. 2013. On the genus Scalopidia Stimpson, 1858 (Crustacea: Bracyhura: Scalopidiidae), with the description of one new genus and three new species. Zootaxa, 3731: 58-76.

Ng, P.K.L. and Castro, P. 2016. Revision of the family Chasmocarcinidae Serène, 1964 (Crustacea, Brachyura, Goneplacoidea). Zootaxa, 4209: 1-182.

Ng, P.K.L.; Devi, S. and Kumar, A.B. 2018. The genus Parilia Wood-Mason, in Wood-Mason \& Alcock, 1891, with description of a new species and establishment of a new genus for P. tuberculata Sakai, 1961 (Crustacea, Brachyura, Leucosiidae). Raffles Bulletin of Zoology, 66: 300-319.

Ng, P.K.L.; Guinot, D. and Davie, P.J.F., 2008. Systema Brachyurorum: Part I. An annotated checklist of extant brachyuran crabs of the world. Raffles Bulletin of Zoology, Supplement 17: 1-286.

Ng, P.K.L. and Kumar, A.B. 2016. Carcinoplax fasciata, a new species of deep-water goneplacid crab from southwestern India (Crustacea: Decapoda: Brachyura: Goneplacoidea). Zootaxa, 4147: 192-200.

Ng, P.K.L. and Richer de Forges, B. 2015. Revision of the spider crab genus Maja Lamarck, 1801 (Crustacea: Brachyura: Majoidea: Majidae), with descriptions of seven new genera and 17 new species from the Atlantic and Indo-West Pacific. Raffles Bulletin of Zoology, 63: 110-225.

Ng, P.K.L.; Shih, H.T.; Ho, P.H. and Wang, C.H. 2017. An updated annotated checklist of brachyuran crabs from Taiwan (Crustacea: Decapoda). Journal of the National Taiwan Museum, 70: 1-185. 
Rathbun, M.J. 1914. A new genus and some new species of crabs of the family Goneplacidae. Proceedings of the United States National Museum, 48 (2067): 137-154.

Sakai, T. 1976. Crabs of Japan and the Adjacent Seas. In three volumes; English Text, pp. xxix+773 pp., Japanese Text, pp. 1-461, Plates volume, pp. 1-16, pls. 1-251. Tokyo, Kodansha Ltd.

Selvaraj, G.S.D. and Kathirvel, M. 1980. Carcinoplax verdensis (Decapoda: Brachyura: Goneplacidae) a new record from Indian waters. Journal of Marine Biological Association of India, 22: 159-161.

Serène, R. and Lohavanijaya, P. 1973. The Brachyura (Crustacea: Decapoda) collected by the Naga Expedition, including a review of the Homolidae. In: E. Brinton, W.A. Newman and W.S. Wooster (eds), Scientific Results of Marine Investigations of the South China Sea and the Gulf of Thailand, 1959-1961. Naga Report, 4: 1-187.

Serène, R. and Vadon, C. 1981. Crustacès dècapodes: brachyoures. Liste prèliminaire, description de forms nouvelles et remarques taxonomiques, in Rèsultats des campagnes MUSORSTOM I. Philippines (18-28 mars 1976), volume 1. Mémoires ORSTOM, Paris, 91: 117-140.

Stebbing, T.R.R. 1923. Crustacea of Natal. Union of South Africa, Fish and Marine Biology Survey. Report No. 3. [For the year 1922 (1924)]. Special Reports: 1-15, pls. 10-16.

Titgen, R.H. 1982. The systematics and ecology of the Decapods of Dubai, and their zoogeographic relationships to the Arabian Gulf and the Western Indian Ocean. Texas A\&M University, Doctor of Philosophy thesis, 269p.

Trivedi, J.N.; Trivedi, D.J.; Vachhrajani, K.D. and Ng, P.K.L. 2018. An annotated checklist of marine brachyuran crabs (Crustacea: Decapoda: Brachyura) of India. Zootaxa, 4502: 1-83.

Wood-Mason, J. and Alcock, A. 1891. Natural History Notes from H.M. Indian Marine Survey Steamer "Investigator", Commander R.F. Hoskyn, R.N., commanding. - No. 21. On the Results of the last Season's Deep-sea Dredging. Annals and Magazine of Natural History, (6)7(39): 258-272. 